BULLETIN Bulletin hispanique

HispaniquE Université Michel de Montaigne Bordeaux

119-1 | 2017

Autorité et pouvoir dans le théâtre du Siècle d'Or

\title{
Rivalidades políticas y enredos amorosos para un héroe legendario
}

Bernardo del Carpio en Francia de Lope de Liaño

\section{Carlos Mata Induráin}

\section{OpenEdition}

\section{Journals}

Edición electrónica

URL: http://journals.openedition.org/bulletinhispanique/4884

DOI: 10.4000/bulletinhispanique.4884

ISBN: 979-10-300-0142-6

ISSN: 1775-3821

\section{Editor}

Presses universitaires de Bordeaux

\section{Edición impresa}

Fecha de publicación: 15 junio 2017

Paginación: 217-230

ISBN: 979-10-300-0141-9

ISSN: 0007-4640

\section{Referencia electrónica}

Carlos Mata Induráin, "Rivalidades políticas y enredos amorosos para un héroe legendario », Bulletin hispanique [En línea], 119-1 | 2017, Publicado el 15 junio 2020, consultado el 11 septiembre 2020.

URL : http://journals.openedition.org/bulletinhispanique/4884 ; DOI : https://doi.org/10.4000/ bulletinhispanique.4884 


\title{
Rivalidades políticas y enredos amorosos para un héroe legendario: Bernardo del Carpio en Francia de Lope de Liaño ${ }^{1}$
}

\author{
Carlos Mata Induráin \\ GRISO-Universidad de Navarra
}

La figure de Bernardo del Carpio a fait l'objet de nombreuses recréations littéraires tout au long du Siècle d'Or espagnol. Cet article se propose d'analyser une comedia très peu connue, Bernardo del Carpio en Francia, de Lope de Liaño, qui met en scène les innombrables exploits du personnage à travers toute l'Europe.

Mots-clés: théâtre espagnol du Siècle d'Or, Lope de Liaño, mythes littéraires, Bernardo del Carpio.

La figura de Bernardo del Carpio contó con abundantes recreaciones literarias en el Siglo de Oro español. Este artículo analiza una comedia muy poco conocida, Bernardo del Carpio en Francia, de Lope de Liaño, la cual nos presenta al personaje realizando innumerables hazañas en Europa.

Palabras clave: teatro español del Siglo de Oro, Lope de Liaño, Mitos literarios, Bernardo del Carpio.

In the Spanish Golden Age, there are a lot of literary works recreating the figure of Bernardo del Carpio. This article analyses a lesser-known play by Lope de Liaño entitled "Bernardo del Carpio en Francia", in which Bernardo is presented carrying out numberless feats in Europe.

Keywords: Spanish Golden Age theatre, Lope de Liaño, Literary myths, Bernardo del Carpio.

1. Este artículo se inserta en el marco del proyecto de investigación FFI2014-52007-P, «Autoridad y poder en el teatro del Siglo de Oro. Estrategias, géneros, imágenes en la primera globalización", financiado por el Ministerio de Economía y Competitividad del Gobierno de España. 
$\mathrm{M}$ uchas han sido, a lo largo de los siglos y en los tres grandes géneros (narrativa, poesía y teatro), las recreaciones literarias del personaje de Bernardo del Carpio: desde los cantares de gesta y el Romancero hasta la novela o el drama históricos del siglo XIX, pasando por el teatro del XVI y el XVII ${ }^{2}$. Esas recreaciones literarias tuvieron especial vigencia en el Siglo de Oro, donde cabe recordar, además del poema épico de Bernardo de Balbuena, varias obras teatrales debidas a Juan de la Cueva, Lope de Vega, Cubillo de Aragón, etc. En este trabajo pretendo analizar otra pieza dramática de esa época, Bernardo del Carpio en Francia, de Lope de Liańo, que nos presenta al personaje realizando innumerables hazañas en Europa: en efecto, en esta obra, tras pasar a Francia y ponerse al servicio del emperador Ludovico Pío, Bernardo logra pacificar Hungría, Bretaña y Gascuña, además de vencer en cuarenta y dos batallas campales.

No puedo entrar ahora en el debate sobre la historicidad del personaje de Bernardo del Carpio que, a los efectos que persigo, no es una cuestión relevante. $\mathrm{Su}$ presencia en las obras de historiadores como Garibay, Morales, Mariana u Ocampo contribuyó a que se creyese en su historicidad, aunque ya Ambrosio de Morales puso en entredicho muchas de las hazañas que de él se relataban. Más recientemente, estudiosos como Menéndez Pidal o Martín de Riquer han defendido el carácter esencialmente ficticio y literario del personaje, que habría sido inventado como contraleyenda española del héroe francés Roldán. Así, por ejemplo, escribía Menéndez Pidal:

La leyenda de Bernardo del Carpio no nace, como las demás leyendas españolas, a raíz de un suceso histórico, sino como necesaria réplica nacionalista a la epopeya francesa carolingia, que durante los siglos XI y XII venía gozando en Espańa de un éxito creciente, a través de variadas versiones españolas (el mismo Roland debía de andar ya por entonces adaptado en un primitivo Roncesvalles español). El Carlomagno liberador de España, cantado por los juglares de allende y aquende el Pirineo, despertó pronto indignación en muchos españoles, que veían en ello un atentado a la empresa nacional de la reconquista, y esta reacción nacional tomó cuerpo poético en la contraleyenda de Bernardo ${ }^{3}$.

Por su parte, Paloma Díaz-Mas afirma taxativamente que «Bernardo del Carpio es un héroe mítico cuya invención parece no tener ninguna base

2. Sobre el personaje de Bernardo del Carpio, en general, ver los trabajos de Entwistle 1928, Franklin 1937, Deforneux 1943, Rubio García 2000, González García 2007 y Bueno 2008. Para su tratamiento literario en el Siglo de Oro, remito a Roses Lozano 1998, Mejía 2004, Ratcliffe 2006, Martínez-López 2010, Loeza 2012, Trambaioli 2012, Roade Riveiro 2013, y Lázaro Niso 2015.

3. Ramón Menéndez Pidal, en su «Introducción» a Romanceros del rey Rodrigo y de Bernardo del Carpio, p. 143. Y sobre el paso a Francia, añade que, según la gesta primitiva, "Después de Roncesvalles, el victorioso Bernardo es reconocido y honrado por su tío el Emperador, y juntos emprenden una campaña de castigo contra los moros. Carlomagno, reconciliado con Bernardo y Alfonso, peregrina a Santiago, y a su vuelta lleva consigo a Bernardo a Francia, donde el héroe de Roncesvalles lucha hasta su muerte victorioso contra los enemigos del Imperio» (p. 144). 
histórica» ${ }^{4}$. En cambio, como paladín de su existencia real se alza Vicente José González García, autor de trabajos que pretenden ser una "defensa vehemente de la historicidad del héroe» ${ }^{5}$, cuya gran hazaña habría sido la participación en la batalla de Roncesvalles del año 808 .

Pero me centraré ya en la comedia que quiero comentar, dedicando unas palabras preliminares al autor y al texto que manejo. En los testimonios conservados, el dramaturgo figura al frente de la obra, y así lo registran distintos catálogos y obras de referencia, como "Lope de Llano»; pero ya Mesonero Romanos y La Barrera señalaron que era un error de transcripción por "Lope de Liaño", dramaturgo documentado de la época áurea que cuenta en su haber con otras piezas teatrales. Sea como sea, son muy escasos los datos existentes acerca de este autor y su producción teatral. Cabe mencionar, sí, que a la altura de 1632 era ya conocido, pues lo menciona Juan Pérez de Montalbán en su "Memoria de los que escriben comedias en Castilla solamente», incluida en su Para todos: «Don Lope de Liaño es tan abundante, ingenioso y fértil para autos y comedias, que en todo tiene muy grande estimación, y toda muy digna de sus aciertos» ${ }^{6}$. Con respecto a su Bernardo del Carpio en Francia (que, a tenor del ultílogo, bien pudiera haberse titulado también La prudencia en el valor), no disponemos de datos acerca de su datación y posibles representaciones, pero la comedia debió de ser muy exitosa, a tenor del gran número de sueltas, tanto del XVII como del XVIII, que se conservan en la Biblioteca Nacional de España (Madrid) y en otras instituciones ${ }^{7}$. Dado que se trata de una pieza hoy día muy poco conocida, me detendré con cierto detalle en el resumen de la acción. De esta forma, a la vez que examino su desarrollo escénico, podré entresacar aquellos pasajes más notables en la construcción del personaje de Bernardo del Carpio, un héroe que, en la corte francesa, se verá envuelto en diversas situaciones de rivalidad política y de enredo amoroso.

\section{DE LAS INTRIGAS CORTESANAS AL SURGIMIENTO DEL ENREDO AMOROSO}

La primera jornada se desarrolla en el salón del Emperador de los francos, poco después de la muerte de Carlomagno. Ha heredado el imperio su hijo Ludovico Pío, cuya esposa también ha fallecido recientemente. Su hijo, llamado asimismo Ludovico, trata de consolarlo, asegurándole que la infanta que viene

4. Palabras preliminares a "Romances de Bernardo del Carpio», en su edición del Romancero, p. 113.

5. Son palabras de Jesús Menéndez Peláez en el «Prólogo» a González García, 2007, p. 11.

6. Ver Mesonero Romanos 1858, p. LIVa; La Barrera y Leirado 1860, pp. 213-214; y Simón Díaz 1984, pp. 303-304, núms. 2140-2150.

7. Un par de ellas s. 1, s. i., s. a. (de las cuales una con la indicación «Núm. 72» antes del título), y otras de Madrid, imprenta de Antonio Sanz, 1739 y 1748; Barcelona, en la imprenta de Pedro Escudèr, 1756 (con la indicación en portada «Núm. 34»); Madrid, en la librería de Quiroga, 1798; Salamanca, en la imprenta de la Santa Cruz, s. a. (con la indicación «Núm. 169» en la portada). He trabajado con un ejemplar de la suelta de 1798. 
para ser su nueva esposa es «el más hermoso prodigio / de belleza que han hallado / las circunstancias del siglo» (p. 1b). Tropezón, el criado de Bernardo, corrobora ese elogio de la dama, a la que su amo ha socorrido al encontrarla en apuros en su camino hacia la corte.

Acompañada de Bernardo, se presenta la que va a ser la nueva emperatriz (no se indica su nombre), y Ludovico Pío, en efecto, queda cautivado por su agradable aspecto. Ella, en su modestia, se compara, en un pasaje de marcado tono calderoniano, con una «yerba frágil» (p. 3a), símbolo muy barroco de la caducidad de toda belleza humana. Por su parte, su dama Rosaura se muestra interesada por el galante español que las ha acompañado. Bernardo y el infante Ludovico se cubren ante el Emperador, actitud presuntuosa que se reprochan en sendos apartes: «¿Quién será aquel arrogante / que así se encaja el sombrero?», dice Ludovico; y Bernardo: "¿Quién será el que junto al rey / tan gallardo se ha cubierto?» (p. 3a). La Emperatriz cuenta que debe su libertad a la espada de Bernardo, cuya valerosa intervención la salvó cuando estaba a punto de caer prisionera de unos enemigos. Bernardo indica que se sentará primero para decir quién es, y que más tarde, puesto de pie, explicará a qué ha venido a la corte francesa. Su actitud despierta reacciones contrarias entre los que le escuchan: el infante Ludovico muestra su desdén con un «Qué arrogante!», mientras Rosaura insiste en su valentía: "Ya quien es dijo su acero» (p. 3b).

Esta escena se ve interrumpida por la llegada de Eroaldo, rey de Dania, vasallo del Emperador. Tras postrarse a sus plantas, indica que ha sido desposeído de su reino por su rival Gofredo, y entonces Ludovico Pío le ofrece una silla. Nótese que su comportamiento es completamente distinto del de Bernardo, quien al llegar se había sentado en presencia del Emperador sin que este se lo hubiese indicado. Tal detalle resulta muy interesante, pues a los ojos del espectador Bernardo queda igualado en esta escena por un lado con el infante Ludovico, por el hecho de permanecer cubierto, y también con el rey de Dania, pues como él se ha sentado junto al Emperador. Eroaldo recuerda que este había enviado a su otro hijo, Lotario, para que le restituyera el reino; pero Gofredo mandó a su encuentro a su hermana Irene, «rico admirable portento / de hermosura» (p. 4a), para que lo entretuviera con falsas demostraciones de amor. De esta forma, durante más de un mes los soldados imperiales se dedicaron al ocio, y cuando más descuidados estaban, Gofredo los atacó y los puso en fuga. Entonces Bernardo, sintiendo que se excita su ardor guerrero, exclama:

\begin{tabular}{cc} 
Bernardo & \multicolumn{1}{c}{ ¡Grande afrenta! } \\
& ¡Santiago, España, a ellos! \\
& Vuestra Majestad perdone, \\
& que este bizarro ardimiento \\
es natural, no fingido.
\end{tabular}

Este es el momento en que Bernardo aprovecha para contar quién es él y la historia de la prisión de su padre, en un pasaje que -aunque extenso- merece la pena reproducir completo: 
Bernardo Yo soy Bernardo del Carpio, sobrino de Alfonso, y nieto de los godos, que la Scitia dio a España por herederos. Contarte, señor, no es justo los admirables sucesos de mi vida, pues la fama los calla por no ofenderlos. Ya sabes de quién soy hijo, $\mathrm{y}$ aquel desdichado yerro de mi padre por amores que le perdonan discretos. En el castillo de Luna le prendió el rey, y encubierto a mis hazañas estuvo, por venganza o por respeto, o por todo, que hay desdichas que se acomodan al tiempo. Súpelo, al fin, de mi madre y enterneciome el exceso de una prisión que veinte años dio sepulcro a un triste viejo. Vacilé con mis sentidos, anulé mis pensamientos, estorbé mis intenciones, aprisioné mis deseos, reducí a valor mi orgullo, rompí a la piedad los ecos y, valido de mí mismo, hice consulta en mi pecho, en que venció la nobleza mas que no el atrevimiento. Serví al rey, y en sus victorias fui el caudillo, y tantas fueron, sí, por Dios, que las columnas, bronces y mármoles tersos, láminas, jaspes y escudos se humillaron con el peso; de suerte que, disuadidos a no declarar mis hechos, por ser tantos se juntaron y unánimes redujeron a una estampa, que soy yo, que no cumplieron con menos (pp. 4b-5a).

Pasa después a enumerar algunas de las hazañas que ha realizado anteriormente, como sus victorias sobre el rey Almanzor de Toledo y el moro de Carrión. Pero todas estas proezas no fueron suficientes para hacer que el rey se apiadase: su padre no fue liberado y terminó falleciendo en su dura prisión. Fue entonces cuando Bernardo tomó la resolución de desnaturalizarse de su señor y marchar con sus gentes a Francia. Su jactanciosa autopresentación entronca con los hechos de la historia de Bernardo difundidos por las crónicas y, sobre 
todo, por el Romancero; mas luego Lope de Liaño prosigue la fabulación de su enredo dramático con detalles fantasiosos de su propia minerva. Es ahora cuando se nos ofrecen más datos de cómo la Emperatriz fue salvada por Bernardo: cuando Seguivio, privado del cetro ducal de Gascuńa, atacó al «bello / escuadrón» (p. 6a) formado por la Emperatriz y sus damas de compañía, Bernardo derrotó y puso en fuga a los asaltantes. Señala que «les desbaraté tan presto, / que entre el vencer y llegar / hay duda cuál fue más presto" (p. 6a). Tras su relato, se levanta y se descubre, mostrando su pretensión de convertirse en vasallo del Emperador, al que dice: «soy leal, vengo a servirte, / manda tú, pues yo obedezco» (p. 6b).

Este modo de presentarse nos retrata perfectamente al personaje de Bernardo, que -en su propia opinión- merece por sus hechos y proezas estar sentado y cubierto ante Ludovico Pío, pero decide ponerse de pie para ofrecerse como vasallo suyo. Cuando el Emperador le da los brazos, y lo llama primo y amigo, la dama Rosaura ve perdidas sus esperanzas amorosas. Todos los cortesanos presentes lo estiman, salvo el infante Ludovico, quien de nuevo comenta despectivo por lo bajo: «iTantas honras a un bastardo!» (p. 6b). Bernardo desea larga vida al infante y este, hipócrita de carácter y comportamiento, le da la bienvenida. Por su parte, el criado Tropezón aporta el contrapunto cómico a la escena, al relatar a su modo el ataque contra las tropas enemigas de Seguivio, y también al relativizar con sus palabras la idealizada descriptio del locus amoenus donde descansaba la Emperatriz que había hecho anteriormente su amo (p. 7a).

De vuelta al tono serio, el Emperador entrega a Bernardo el bastón de general y determina que parta a Dania con su rey para derrotar a Gofredo. Él, por su parte, irá a Gascuña para vencer a Seguivio. De esta forma quedará castigada la arrogancia de uno y el atrevimiento de otro. Y si Eroaldo se muestra agradecido por la decisión imperial, Ludovico en cambio manifiesta sus celos en un nuevo aparte: «¿Esto sufro? ¿Esto consiento? / ¿A un extraño general?» (p. 7b). Sin embargo, en voz alta, otra vez disimula y manifiesta buenos deseos al español: «Los cielos, / Bernardo, os guarden dichoso» (p. 7b). El Emperador pide a Bernardo que respete mucho a su otro hijo, Lotario, detalle este que será importante en el desenlace de la obra.

El siguiente bloque de acción sucede en un escenario alejado de la corte y con nuevos personajes: «Vanse, y sale Irene de cazadora con arco, llorando, y Oronte, muy viejo, vestido de pieles» (p. 7b). Irene, gran princesa de Colonia, hermana del bastardo Gofredo, se queja a su tío Oronte, en un bello discurso, de que la ha engañado, pues el enemigo al que le pidió que entretuviera tiene un carácter muy distinto de aquel con que lo había descrito. Y aclara que han sido fingidas todas las señales amorosas que le ha dado a ese príncipe, que se enamoró de ella nada más verla. Las palabras de Oronte permiten completar la historia: cuando Gofredo se apoderó del reino de Dania, llegó para recuperarlo Lotario con un «arrogante ejército». Oronte quiso que Irene lo distrajera con su «belleza admirable», circunstancia que aprovechó Gofredo para derrotar a los imperiales. El plazo de la tregua firmada entonces se cumple ahora, y Oronte quiere que Irene siga fingiendo que ama a Lotario para mantenerlo inactivo. 
Tenemos, por tanto, que el infante Lotario se comporta como un mal general, pues abandona sus deberes militares para seguir esta aventura amorosa (trueca a Marte por Venus); de hecho, viene siguiendo a Irene, a la que encuentra junto a unos sauces y un arroyuelo ${ }^{8}$. Llega también Bernardo "con bastón de general" (acotación en p. 8a), y el español queda súbitamente enamorado de ella al verla: «Esta es Irene, ya el peligro es cierto: / si a Lotario venció, a mí me ha muerto" (p. 10a), se entiende, claro está, que de amor. También la dama queda impresionada: en efecto, si la "peregrina hermosura» de Irene ha dejado sin sentido al español, la "gentileza admirable» de Bernardo la cautiva por igual a ella. Pero ambos pertenecen a bandos enemigos y, en versos alternos, cada uno le advierte al otro que debe guardarse de su furia. Se trata de una bella escena para rematar la jornada, en la que el intercambio que hacen de unas bandas al separarse nos hace presumir un desenlace feliz para la comedia, que se mueve ahora por los derroteros del enredo amoroso.

\section{NUEVAS ENVIDIAS POLÍTICAS Y RIVALIDADES AMOROSAS}

La jornada segunda se abre con una escena en la que Lotario y Bernardo, en la antesala del Emperador, discuten sobre quién debe entregarle a Irene, que ha sido hecha prisionera. Bernardo, que reprocha el orgullo de Lotario, resume diciendo: «Yo llegué, peleé y vencí» (p. 10b), formulación que recuerda el famoso «Veni, vidi, vici» de Julio César tras su victoria de Zela. A diferencia de Lotario, que ha estado entretenido en delicias de amor, él ha vencido la batalla, en la que dejó 30.000 muertos y otros tantos prisioneros, y en la que Irene quedó por despojo de guerra suyo. Cabe destacar en este punto la amplia serie de referencias elogiosas aplicadas a Bernardo: además de ser comparado con César por su prontitud en vencer, por su belleza parece un Adonis, etc. Y no son solo los elogios a su persona, sino que se añade la caracterización negativa de otros personajes que podrían hacerle sombra en la corte, pero a los que Bernardo supera en empeño, valor y constancia: los ejemplos negativos de sus rivales políticos y/o amorosos potencian el retrato positivo del héroe español, un hombre "que da reinos por su espada / y por su lealtad los deja» (p. 10b).

Tenemos, por tanto, que Lotario y Bernardo rivalizan por la posesión amorosa de Irene, quien habla del amor haciendo uso del léxico filosófico (sentidos y potencias, alma y cuerpo, etc.), y responde a ambos galanes que, si bien su cuerpo está prisionero, tiene el alma en libertad: ella, empleando una conocida imagen emblemática, afirma que es "peña altiva / siempre libre» que se opone al contraste del mar (p. 11a). Sin embargo, también reconoce que tiene un dueño absoluto, aunque no dice quién es. «Respondió como quien sabe», pondera Bernardo; y corrobora Tropezón: «Siempre la he visto discreta» (p. 11b). La reacción de Lotario es completamente diferente: dice que Irene

8. Se inserta aquí un pasaje de descripción petrarquista (pp. 8b-9a) y una evocación del mito de Apolo persiguiendo a Dafne. 
le está perdiendo el respeto, «pero podrá la violencia / lo que el amor no ha podido, / [...] / que soy Lotario y soy César» (p. 11b), palabras con las que queda totalmente desautorizado como caballero galán. Añade además que no ha de admitir la competencia amorosa de un bastardo, lo que hace que Irene prevenga a Bernardo de esta forma:

$\begin{array}{ll}\text { Irene } & ¡ \text { Ay, español, Dios te guarde, } \\ \text { porque ya la envidia empieza } \\ \text { con el poder, y son juntos } \\ \text { monstruo de siete cabezas! (p. 11b). }\end{array}$

Bernardo, en cambio, se muestra atento con Irene, porque aunque ella le haya podido agraviar, «la majestad se respeta / como a Dios» (p. 11b). Y añade unas palabras importantes para completar su retrato: «Soy vasallo, y no me toca / más de guardar la obediencia» (p. 11b). Para no enfrentarse a Lotario, pide al valor que "ponga candado a la espada / y freno ponga en la lengua, / [...] / que es la mayor valentía / vencerse a sí mismo, y yerra / quien llevado de su orgullo / del honor no se aconseja, / que imita a Dios quien consulta / en el valor la prudencia» (p. 12a). Lotario insiste grosero: «Gozarela, ¡vive el cielo!», y Bernardo responde: "con ella, que es mi igual, he de casarme» (p. 12a). Quedan patentes, pues, los diferentes propósitos que tienen ambos rivales.

Más adelante, el Emperador y la Emperatriz dan la bienvenida a Bernardo y comentan la feliz victoria de su acero y la pacificación del reino de Dania. La hermosa Irene, que es hija del primo de la Emperatriz, es estimada en la corte. Delante de testigos, Bernardo y Lotario se elogian mutuamente en réplicas alternas. Luego, el relato de los sucesos de la campańa militar se hace a tres voces: comienza a contarlos Irene, prosigue Lotario y concluye Bernardo, quien venció y mató al general contrario, bizarro y orgulloso: «mirele, y no me vi, que si me viera / de mi mismo valor temor tuviera» (p. 14a). Los soldados querían que se le entregase el reino, pero él prefirió dar el cetro a su dueño Eroaldo: «al vulgo me negué y a la corona» (p. 14b), indica, y explica que «No fue aquesto, señor, vana apariencia; / mi sangre sí, que en mi lealtad se abona» (p. 14b). El contrapunto humorístico viene dado en esta ocasión por el quiromántico Malgesí, que desea apoderarse de los mil escudos que el Emperador ha dado a Tropezón por haber peleado (así, al menos, lo ha afirmado él) como valiente soldado.

La trama de enredos amorosos se complica con la intervención de Rosaura, dama de la Emperatriz enamorada de Bernardo y celosa, por tanto, de Irene, que en una escena a solas muestra su decisión de dar celos a su rival. En un momento de introspección paralelo, Bernardo, igualmente solo, analiza su situación, contrastando su habitual decisión y arrojo con la inquietud amorosa que ahora siente:

$$
\begin{aligned}
& \text { Bernardo } \text { ¿Yo amor? ¿Yo desasosiego, } \\
& \text { cuando en mí apenas cabía } \\
& \text { mi furor, mi valentía? } \\
& \text { Pero bien le pintan ciego, }
\end{aligned}
$$


que si él una vez me viera, cuando el arco disparara, ni la flecha me tirara, ni aun los ojos me volviera (p. 15a-b).

Rosaura pone en marcha su plan: conversando con Bernardo, le pide que le cambie por un diamante la banda que le dio Irene. Esta, que los observa al paño, queda en efecto celosa. También la Emperatriz contempla toda esta escena, y más tarde llegará Lotario, que queda al otro paño. Irene, enfadada, se dirigirá a Bernardo apelando a su lustre y al decoro, y afirmando que no lo adora, que el cariño no es pasión, "porque no hay inclinación / en mujeres de mi estado" (pp. 15b-16a). Reconoce que darle la banda fue una bizarría, pero esa acción ya está puesta en olvido, "que si una banda es del viento, / de un desaire es la crueldad» (p. 16a). Y advierte al español que mude de pensamiento si ha de amar en palacio. Bernardo responde con estas razones: «En las montañas, señora, / no estudian leyes de amor; / cifras sí para el valor / desde su primera aurora» (p. 16a). Y en un pasaje plagado de agudezas conceptistas justifica el trueque diciendo que cambiar la banda («volante prenda») por el diamante fue hacer su amor más constante, pues así se acrisolaba su fe, ingeniosa argumentación que hace pensar a la Emperatriz: "Hasta en el enamorar / tiene española braveza» (p. 16b).

Al final, la Emperatriz sale de su escondite e interrumpe la conversación; a Bernardo le dice que su prima Irene «merece mucho agasajo, / que es noble, es hermosa, es rica, / y estará bien empleado / cualquier príncipe con ella» (p. 16b); y reconoce que también merece mucho Bernardo, al que elogia en estos términos:

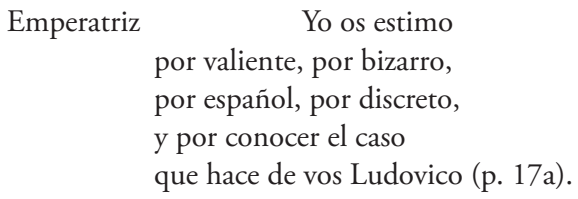

Lotario, que sigue observando todo al paño y se siente celoso y agraviado, se queja de que la Emperatriz se porta con él como madrastra; y piensa que su atrevimiento es todavía mayor cuando escucha de su boca que el Emperador quiere dar parte de sus estados a sus hijos, para lo cual se quiere aconsejar con Bernardo. La Emperatriz desea proteger los derechos de su hijo Carlos, que es todavía muy niño, frente a sus hermanos ( «Es arrogante Lotario, / es Ludovico impaciente, / y no son hijos», p.17a); y para ello acude al noble Bernardo, cuyo acero es el sagrado al que se acoge su causa: «yo de quien sois me valgo» (p. 17a). Por supuesto, el noble Bernardo le asegura que la va a servir bien, con lo que de nuevo se pone de manifiesto su profunda caballerosidad.

También el Emperador, al que vemos hablando a solas, muestra su intención de dejarse aconsejar por Bernardo en los asuntos políticos: aunque puede consultar con su consejo de Estado, existen diversos pareceres y necesita escuchar a personas discretas: "Justo es que tengan los reyes / donde humanar 
lo sagrado / con llaneza» (p. 17b). Cuando se encuentra con Bernardo, le indica que tome asiento y se cubra. «Hechura de vuestra mano / soy, no puedo replicar» (p. 17b), contesta este. Vemos que se reproduce así la situación de la primera jornada, con la diferencia de que ahora es el Emperador quien autoriza al español a permanecer sentado y cubierto. Ocurre que Ludovico Pío quiere repartir las provincias entre sus hijos y pide su parecer a Bernardo. Mientras el infante Ludovico escucha al paño, Bernardo le aconseja que dé Italia, que está sin rey, a Lotario; que haga rey de Baviera a Ludovico; y que al niño Carlos lo nombre heredero de Panonia, con lo que a él le quedarían el Imperio y las Galias. El Emperador pondera la prudencia de su sobrino (así lo llama), lo abraza y le ofrece el gobierno de su corona, mientras Ludovico comenta aparte, sorprendido y enfadado: «iQue le aconseje un extraño / y él lo admita! ¡Vive el cielo!» (p. 18a).

Más tarde, reunidos los dos hermanos, Ludovico y Lotario, envidiosos del español, se quejan de tanto favor alcanzado y de que se le dé el gobierno a un bastardo. Deciden juntar sus vasallos y alzarlos en armas (se convierten así en rebeldes contra su padre), y la jornada concluye con un contundente: "iMueran, mueran los contrarios!», gritado por los dos hermanos a coro.

\section{LA REBELIÓN DE LOS HIJOS Y EL PERDÓN PATERNO}

La tercera jornada va a desarrollar el tema de la rebelión de los hijos contra su padre Ludovico Pío. En efecto, Lotario asalta la ciudad, defendida por Bernardo. El Emperador se lamenta de la traición de sus hijos, que considera un justo castigo de Dios por sus culpas. Lotario y Ludovico justifican el haber tomado las armas contra él diciendo que Bernardo gobierna todos sus reinos sin prudencia y sin aviso; y a la reina le reprochan su falta de cariño (no ha sido una madre para ellos) y la acusan de que, puesta de acuerdo con el español, pretende dar el Imperio al benjamín Carlos. El Emperador reconoce que «Bernardo es mi sangre, y es mi amigo» (p. 19a), y pide que no le llore nadie, porque «no es bien discurso humano / contra decretos divinos / [...] / y no hay hazaña que iguale / como el vencerse a sí mismo»" (p. 19b). Luego manda a Bernardo que vaya a Dania a pedir ayuda, momento que el espańol aprovecha para enumerar las principales hazañas que ha realizado a su servicio:

\begin{tabular}{|c|c|}
\hline Bernardo & $\begin{array}{l}\qquad \text { Si sois servido, } \\
\text { morir quiero a vuestros ojos; } \\
\text { mas quien en vuestro servicio } \\
\text { ha sujetado la Hungría, } \\
\text { ha puesto ley a los cimbrios, } \\
\text { dado ley a la Bretaña } \\
\text { y a la Gascuńa castigo, } \\
\text { y en cuarenta y dos batallas } \\
\text { más banderas he ofrecido }\end{array}$ \\
\hline
\end{tabular}

9. El vencimiento de uno mismo es un leit motiv importante en la obra. 
a vuestras plantas que tiene

hojas este bosque umbrío,

no ha de temer (p. 19b).

El Emperador dice que sus hijos son dos muchachos llevados de su albedrío, «sin aviso, / sin razón, sin ley, sin Dios» (p. 19b), e insiste en que el cielo lo castiga por culpa de sus pecados. Pide a Bernardo que, de camino, deje a la Emperatriz en un monasterio en Colonia, y también a su hijo Carlos, al que bendice, pues es el único que sigue la voluntad de su padre y tiene los bríos de su abuelo, el gran Carlo Magno. Sigue una escena con réplicas alternas de Bernardo e Irene, que quiere marchar con la reina, aunque sea incumpliendo el precepto del Emperador. Se hace patente aquí el conflicto entre el amor y el honor, que exige siempre notables sacrificios.

Avanza la acción y el Emperador es apresado por sus hijos, a los que advierte: «Mirad que os he dado el ser, / y que un delito tan grave / castigar el cielo sabe, / y contra Dios no hay poder» (p. 21a). "Yo soy César», le replica Lotario; Ludovico, por su parte, reprocha a su padre que favorezca a los extraños en perjuicio de los naturales: "Gobernar los extranjeros / nunca se vio permitido" (p. 21a). Ludovico Pío queda en prisión en la torre del homenaje con cien soldados de guardia ${ }^{10}$, nuevo ultraje que le hace clamar: «esto es ya tentar al cielo» (p. 21b).

El dramaturgo introduce en este punto una escena anticlimática, de distensión cómica, la protagonizada por Tropezón y Malgesí (la historia de la losa partida con una inscripción que remite a un supuesto tesoro). Después, Bernardo ataca con su gente, proclamando: «El cielo me guarda para el castigo / de tan loco atrevimiento» (p. 23a). Estas palabras resultan reveladoras, porque en este tramo final de la comedia el héroe español va a adoptar una nueva función: castigar la rebelión de los hijos del Emperador. Para que no mueran vasallos inocentes, Bernardo pide a Lotario que luchen solo ellos dos para ver cuál tiene mayor justicia; le dice también que no quiere matarlo, sino rendirlo, por cumplir el precepto que le dio su padre.

Mientras tanto Eroaldo, que ha venido de Dania con 100.000 soldados en defensa de su emperador, pide ayuda al «Bernardo espańol» (p. 23b) para rescatar a Irene, que está presa. De nuevo combaten en Bernardo el amor y el honor. Se oyen gritos que aclaman a Lotario como César supremo, y afirma este que lo será a pesar de todo el mundo. Bernardo consigue liberar al Emperador de su prisión y lo saca en brazos; una vez a salvo su señor, embiste contra sus enemigos: «mi acero / no ha de dejar hombre vivo, / que es centella, es rayo, es fuego" (p. 23b). Dada la furia del español, Lotario corre grave peligro de morir, pero el Emperador ordena envainar a todos: aunque le ha agraviado, es su hijo, y pide a sus amigos y deudos que interrumpan la lucha. Les dice que el «supremo vice-Dios» (el Papa), que está cercado de «inhumanos agarenos», solicita ayuda y Ludovico Pío determina que acudan todos a librarlo. El infante

10. Esta prisión de Ludovico Pío, casi padre para Bernardo, guarda cierto paralelismo con la prisión del conde de Saldaña. 
Ludovico acepta el plan, que le parece justo; Lotario, en cambio, se marcha de la corte. Bernardo asegura que, tras ir a Roma a socorrer a la Iglesia, buscará otro reino; el único premio que pide al Emperador es que le conceda la mano de Irene, y esta, que confiesa ser su hechura, acepta. A su vez, el Emperador promete casar a Rosaura con un príncipe de su sangre, y manifiesta que perdona a sus dos hijos.

\section{A MODO DE CONCLUSIÓN}

La lectura de Bernardo del Carpio en Francia nos revela una obra más interesante de lo que a primera vista pudiera parecer: comienza como un drama bélico, de hazañas militares; pero pronto se transforma en comedia de enredo amoroso (pues la rivalidad de Bernardo y Lotario no afecta solo a las armas, sino que ambos se disputan el amor de Irene); y tiene también sus ribetes de drama de poder (con el tema de la rebelión de los hijos frente al padre, la idea del rey como representante de Dios en la tierra y la consiguiente visión providencialista de la historia, la necesidad de que el monarca cuente con buenos consejeros, etc.). En cuanto a la presentación de Bernardo del Carpio, aunque se recuerdan los hechos previos de su historia en Espańa, la acción comienza cuando decide pasar a Francia y ponerse al servicio de Ludovico Pío. Es arrogante, pero fiel; conquista reinos, pero no se los queda para sí, sino que, como buen vasallo, los entrega a su nuevo señor. Y su figura queda engrandecida por contraste con los dos hijos del Emperador, soberbios, envidiosos y traidores (en especial, Lotario). Por otra parte, estamos ante una comedia que maneja muy variados registros: épico, amoroso-caballeresco, culto..., y que incluso presenta pequeños atisbos de comedia de magia (en las escenas humorísticas protagonizadas por Malgesí y Tropezón). Desde el punto de vista estilístico y del ornato retórico, se trata de una pieza bastante elaborada (abundan los ejemplos de anáforas, paralelismos, paréntesis exclamativos...), en la que se introducen diversas alusiones mitológicas y se juega con los valores emblemáticos y de la tradición animalística. En suma, es una obra en la que Bernardo del Carpio queda retratado como guerrero vencedor en mil batallas y pacificador de reinos en Europa, galán enamorado y enamorador, caballeresco protector de la Emperatriz (primero la salva de los enemigos que la atacan y luego se ofrece para defender los derechos de su hijo Carlos), consejero del Emperador y, al final, colocándose en un peldaño superior, instrumento divino para castigar la rebelión de los hijos de Ludovico Pío. En definitiva, la comedia de Lope de Liaño constituye un eslabón más, no exento de interés, en la extensa cadena de obras literarias que a lo largo del tiempo han recreado el personaje histórico-legendario de Bernardo del Carpio. 


\section{Bibliografía}

Bueno Gustavo, «Bernardo del Carpio y España», El Catoblepas. Revista critica del presente, 72, 2008, pp. 1-10.

Deforneaux Marcelino, «L'Espagne et les légendes épiques francaises. La légende de Bernardo del Carpio", Bulletin Hispanique, 45, 1943, pp. 117-138.

Entwistle William J., "The Cantar de gesta of Bernardo del Carpio», Modern Language Review, 23, 1928, pp. 307-322 y 432-452.

Franklin Albert B., "A Study of the Origins of the Legend of Bernardo del Carpio", Hispanic Review, 5, 1937, pp. 286-303.

González García Vicente José, Bernardo del Carpio y la batalla de Roncesvalles, Oviedo, Fundación Gustavo Bueno-Oviedo XII Siglos, 2007.

La Barrera y Leirado Cayetano Alberto de, Catálogo bibliográfico y biográfico del teatro antiguo español, desde sus orígenes hasta mediados del siglo XVIII, Madrid, Imprenta y Estereotipia de M. Rivedeneyra, 1860. Ed. facsímil, Madrid, Gredos, 1969.

Lázaro Niso Rebeca, «La leyenda de Bernardo del Carpio y su proyección en la literatura», Cuadernos de Aleph, 7, 2015, pp. 79-95.

Llano Lope de, Bernardo del Carpio en Francia, Madrid, en la Librería de Quiroga, 1798.

Llano Lope de, Bernardo del Carpio en Francia. Comedia famosa, en Comedias varias de diferentes autores de España, Parte X, en Spanish Drama of the Golden Age, 15621850, microfilm from the Comedia Collection of the University of Pennsylvania, reel 14, núm. 631.

Loeza Alejandro, "Justicia y poder en la representación de Bernardo del Carpio de Juan de la Cueva», en Oana Andreia Sâmbrian, Mariela Insúa Cereceda y Antonie Mihail (eds.), La voz de Clio: imágenes del poder en la comedia histórica del Siglo de Oro, Craiova, Editura Universitaria Craiova, 2012, pp. 90-101.

Martínez-López Maribel, «La leyenda de Bernardo del Carpio vista por el dramaturgo áureo Álvaro Cubillo de Aragón», Espéculo. Revista de Estudios Literarios, 44, 2010, s. p.

Mejía Alma, «De la comedia áurea al pliego suelto narrativo: el caso de Bernardo del Carpio", en Isaías Lerner, Roberto Nival y Alejandro Alonso (coords.), Actas del XIV Congreso de la Asociación Internacional de Hispanistas, New York, Juan de la Cuesta, 2004, vol. 2, pp. 383-387.

Menéndez Pidal Ramón, Romanceros del rey Rodrigo y de Bernardo del Carpio, ed. y estudio a cargo de Rafael Lapesa, Diego Catalán, Álvaro Galmés y José Caso, Madrid, Gredos, 1957.

Mesonero Romanos Ramón de, Dramáticos contemporáneos a Lope de Vega. Colección escogida y ordenada, con un discurso, apuntes biográficos y criticos de los autores, noticias bibliográficas y catálogos, Madrid, M. Rivadeneyra, 1857-1858, 2 vols.

Ratcliffe Marjorie, "Honor y legitimidad: Bernardo del Carpio en el Siglo de Oro", en Anthony J. Close (ed.), Edad de Oro cantabrigense. Actas del VII Congreso de la 
Asociación Internacional del Siglo de Oro (AISO), Madrid / Frankfurt, Iberoamericana / Vervuert, 2006, pp. 521-526.

Roade Riveiro Jessica, «El origen de Bernardo del Carpio en el teatro de Lope de Vega», en Carlos Mata Induráin, Adrián J. Sáez y Ana Zúñiga Lacruz (eds.), «Festina lente». Actas del II Congreso Internacional Jóvenes Investigadores Siglo de Oro (JISO 2012), Pamplona, Servicio de Publicaciones de la Universidad de Navarra, 2013, pp. 403414.

Roses Lozano Joaquín, «Algunas consideraciones sobre la leyenda de Bernardo del Carpio en el teatro de Lope de Vega», Inti. Revista de literatura hispánica, vol. 1, number 28, article 10, otońo 1988, pp. 88-105. Disponible en <http:// digitalcommons.providence.edu/inti/vol1/iss28/10>.

Rubio García Luis, «Historia y poesía: Bernardo del Carpio», Estudios Románicos, 12, 2000, pp. 7-30.

Simón Díaz José, Bibliografía de la literatura hispánica, Tomo XIII, Madrid, CSIC, 1984.

Trambaioli Marcella, «Bernardo del Carpio y los comienzos de la autopromoción del joven Lope de Vega», en Héctor Brioso Santos y Alexandra Chereches (eds.), "Callando pasan los ligeros años...": el Lope de Vega joven y el teatro antes de 1609, Madrid, Liceus, 2012, pp. 69-90. 